\title{
Behavioural Economics and Social Economics: Opportunities for an Expanded Curriculum
}

\begin{tabular}{|r|l|}
\hline Journal: & International Journal of Social Economics \\
\hline Manuscript ID & IJSE-05-2018-0250.R1 \\
\hline Manuscript Type: & Research Paper \\
\hline Keywords: & Behavioural economics, White-Collar Crime, Global Financial Crisis \\
\hline \multicolumn{2}{|r}{} \\
\end{tabular}

\section{SCHOLARONE ${ }^{\text {TM }}$ Manuscripts}




\section{Behavioural Economics and Social Economics: Opportunities for an Expanded Curriculum}

\section{Introduction}

The global financial crash (GFC) was neither predicted nor alleviated by orthodox neo-classical economics, thus calling into question the predictive power and policy efficacy of the discipline. The contention of this article is that the GFC exposed orthodox economics as both over-extended and over-confident in its under-socialised conception of economic activity. Nevertheless, the ontological and epistemological assumptions of neo-classical economics, which 'privilege an instrumental approach based on simplistic utilitarian premises', remain dominant in business schools (Painter-Morland, 2015).

Teaching across business school disciplines is therefore directed by the established orthodoxy of 'homo economicus', a mechanistic idealisation of narrow self-interestedness. This orthodoxy is not however, conducive to social economics (Boyle, 1999, p. 56), which posits a contrasting, and rival way of thinking about economics that rejects the core rational assumptions of neo-classical economics. For instance, social economics refutes the belief that the pursuit of self-interest in the market will enhance and protect the common good. Social economics is also characterised as a 'distinctly pluralistic group encompassing different points of view', which reflects its intellectual history, which is also diverse (Smelser and Swedberg, 2005), though it would be reasonable to point to that contemporary interest in social-economic phenomena being stimulated by Etzioni's book 'The Moral Dimension' (1998). Core social economic notions, include the view that the economy is embedded in wider society, as well as a recurring emphasis on social justice and economics for the common good (Lutz, 2002). 
This paper will make a case in favour of an expansion of the economics curriculum to incorporate behavioural economics (BE). The paper will contend that $\mathrm{BE}$ can be connected to social economics as they are both heterodox in that that study and analyse economic phenomenon outside of a neo-classical framework. The aim is to contribute to the argument for an expanded curriculum, beyond the framing assumptions of neo-classical rationalism. The logic of this aim is based on the GFC as having exposed the limitations of the orthodox narrow Hobbesian view of human agency, which consequently requires an expanded analysis of economics. This paper will also support its case by reviewing BE to make the case that this literature can be connected to social economics. This assertion is based on shared connections, including the importance of Kantianism in behavioural economics (Etzioni, 1988), and in social economics (Etzioni, 1999; White, 2011). These connections will be discussed as a common point of reference point, or ties that can serve to broker links between these two theoretical' close relatives' (Giald et al, 1984).

This teaching case was also inspired by the developing literature critical of business school pedagogy, including economic teaching that has become more acute since the GFC. This literature stream has noted that '...resentment against the MBA is visible everywhere' (2013). Podolny for instance, a former dean of Yale business school, has concluded that MBA programs under-estimate the importance of ethics, typically emphasizing their cardinal ambition to '...augment student income' (2009: 63). Giacalone and Wargo, have also made a convincing case that, 'The Roots of the Global Financial Crisis Are in Our Business Schools' (2009). In synopsis this literature is critical of the business school curriculum for being too narrowly focussed on self-interestedness as defined by rational choice economics, at the expense of 
neglecting social economic concerns of ethical and wider role and responsibilities of business, including neglecting the social economic priority for justice. As a result there have been too many examples of narrow self-interest and corruption involving MBA graduates who operate as if 'the bottom line' is the only arbiter of legitimacy or success in economic activity. Furthermore, the case will highlight the structural factors and cultural forces that facilitated this crime, and other financial frauds that were pervasive before the GFC.

The article will proceed with an explication of the theoretical context of the teaching, with a discussion of the relevance of behavioural economics (BE) for analysing white-collar crime. This section will be followed by discussion of the social economic perspective on the limits and potential of behavioural economics, which will identify connections between these heterodox economic perspectives. The methodology of the case study based teaching will then be introduced and justified. Next a discussion of the social economic characteristics of the Madoff case will be delineated, and then the article will discuss corruption and white-collar crime.

Student reflections on the case will then be discussed, with reference to BE and social economics. Finally, the article will be a conclude with a discussion of how the case has added weight to the argument for a teaching curriculum framed by an expanded set of BE and social economic assumptions.

\section{The Theoretical Context of the Teaching: Behavioural Economics \\ 'Today, homo economicus is in retreat, and this is where 'behavioural economics comes in' (Streek, 2010, p. 390).}


One response to these limitations in mainstream economics' 'rational model' has been to stimulate interest in behavioural economics, which adds psychological insights to economic analysis. According to Camerer and Loewenstein, behavioural economics increases the explanatory power of economics by providing it with more realistic psychological foundations (2004: 3). For example, Thaler has conducted research that established fairness as a major research topic in economics (1980). BE argues for the importance of how the mind works, to include anchoring effects, narrow framing, heuristics and excessive coherence in decision making (Tversky and Kahneman, 1974). In psychology behaviourists concentrate on observing responses to external stimuli; that is, they research observable phenomena. In the behavioural economic approach, psychology and economics are fused together to offer a humanistic analysis and a theory of behaviour in the economy. BE therefore stands as a heterodox approach to the mainstream rational agent model, both as theory of motivation and as a method of analysis.

The seminal behavioural economics publication was by Tversky and Kahneman (1974), which was later expanded and popularized by Kahneman (2011). BE is concerned with cognition and the view that, '...the mind is subject to systematic errors' (Kahneman, 2011: 10). It follows therefore that the BE understanding contradicts the extreme form of the rational agent model, because individuals make mistakes and therefore need to be protected from their rationally chosen, but nevertheless bad decisions (Ibid: 412-13). Thaler can also lay claim to be the leading behavioural economic critic of mainstream economics (2015). The importance of this research was recognized in the awarding of a Nobel Prize for Economics to Kahneman in 2002, and Thaler in 2017. 
The key ideas in this BE include a dualistic view of the mind between, ' $\ldots$ intuitive system one, which does the fast thinking, and the effortful and slower System 2, which does the slow thinking, monitors system 1, and maintains control as best it can within its limited resources' (Ibid: 408). Other concepts that describe how the mind works include, anchoring effects, narrow framing, heuristics and excessive coherence. For illustration, Holcomb et al, have drawn on Tversky and Kahneman's heuristic insights to develop a more accurate understanding of variations in how knowledge evolves (2009). These scholars emphasis the significance of 'system one' thinking in experiential and vicarious learning, with reference to three heuristics: the availability heuristic, the representative heuristic and the anchoring and adjustment heuristic (Tversky and Kahneman, 1974).

For the paper's case study on corruption and white-collar crime, behavior BE informed the teaching in terms of its sub-division on behavioral ethics. Kahneman's comments on 'econs v humans' were discussed to highlight the limitations of economic rationality, which was contrasted with the behavioral ethics perspective (2011: 343-344). BE has been defined as the study of 'individual behavior that is subject to or judged according to generally accepted moral norms of behavior' (Treviño, Weaver, and Reynolds, 2006: 952). This case study was inspired by a behavioural ethics theme of 'reactions to unethical behavior' (De Cremer, Mayer \& Schminke, 2010). This theme can be related to a behavioural focus on deontic justice; that is justice is valued for its own sake (Cropanzano, Goldman, \& Folger, 2003; Folger, 1998; Folger \& Cropanzano, 2001). 
This case study was also holistic and consequently secured within the social economic mainstream, in being inter-disciplinary drawing in theories and insights from various disciplines, including criminology, sociology and history.

\author{
A Social Economic Perspective on the Limits and Potential of Behavioural Economics \\ This paper contends that behavioural economics can contribute to the teaching of socio- \\ economics based on three observations that are detailed below. At the outset of this section \\ however, there is an important counter-argument that deserves elaboration, in which BE stands \\ in opposition to social economics. In this purview BE, with its 'libertarian paternalism' (Thaler \\ and Sunstein, 2008) is interpreted as denying the individual dignity and autonomy, rendering \\ them agents that are too inefficient in the market that consequently need to be corrected. Thus, \\ $\mathrm{BE}$ in this reading is a literature stream predicted on the sole idea of improving the efficiency of \\ the free-market. It follows that $\mathrm{BE}$ is also be accused of reductivism, limiting its scope to \\ analysing and rectifying the consequences of less than optional or irrational choices. BE is \\ therefore taken as limiting its analytical lens to a narrow focus on how judgments under- \\ uncertainty are made, without recourse giving any weight to social economic factors, including \\ social structure, resources allocation and matters of justice. In summary, in this reading BE is \\ interpreted as being antipathetic to social economics, as its focus is taken as being entirely bent \\ on improving the efficacy of the market, that is, as an economic approach that is very much \\ within the mainstream of orthodox rational economics.
}

\begin{abstract}
A first response to this line of reasoning is to note that $\mathrm{BE}$ does not accept the neo-classical method of analysis, and in consequence is heterodox to the neo-classical paradigm. BE rests on
\end{abstract}


the understanding that ' ...humans are not well described by the described by the rational agent model' (Amos, 211, p 411). Furthermore, adherents of BE note that freedom has a cost and '...reject the extreme form of the rational agent model' (ibid, p.412). BE therefore acknowledge the urgency of addressing the problem of protecting people from their bad decisions: in rational choice economics it is assumed that these mistakes are not made and hence require no corrective. From this understanding BE, because it notes a key limitation of rational choice, has a connection to social economics, which also emphasises the limits of 'homo economicus'.

Second, the most telling bridge between BE and social economics is in their shared deontological assumptions. Deontology focusses on intentions, whereas utilitarianism is concerned with consequences; put another way deontology is rule-based whereas utilitarianism is a consequence-based. It has been previously observed that social economics can be aligned with deontology; that is as a Kantian correction of the utilitarianism of neo-classical economics (Etzioni 1987, 1999). The question is whether BE can be connected to deontology, to link the perspective with social economics?

The more obvious response is to assert that Kantian deontology and liberalism is best utilised to criticise BE. In this interpretation the dignity of the individual requires that they are allowed to pursue their choices at liberty; that is with minimal interference of the state or any other external authority, a view that runs opposite to the core nostrums of BE. Thus, in a liberal reading of Kantianism, it is taken as being in favour of the autonomy of individuals to make context bound judgements with dignity, individualism and the strong autonomy. 
There is however, an alternative perspective that can be taken on the Kantian deontology and approach to economics, which aims to introduce social responsibility into his analysis. In this appreciation there is a more nuanced analysis of Kantian economics, who it is worth noting favoured taxation to fund welfare provision, and therefore was interested in the core social economic concern of justice. Etzioni, furthermore has noted that 'moderate deontology' recognises intentions as integral to decision making (2011). One could therefore contend that $\mathrm{BE}$, with its focus on improving outcomes could be conceptualised to incorporate social economic concerns into decision making, in part as individuals are embedded in social economic factors that affect their intentions.

Third, decision making is usually more complicated than indicated by the academic divide between the philosophy indicates with its separation of deontology and utilitarianism (Smith, et al, 2015). Therefore although theoretically the two perspectives are discreet and arguably in opposition, in quotidian economic activity deontological intentions and utilitarian consequences are integrated, and self-reinforcing, which accords with the Kantian view of the divided self. In consequence, both perspectives can be considered to be at play in decision making, as are BE and social economic factors. This paper is based on the assumption of an integration of all of these perspectives to give a more complete understanding of human choice and action. This assumption therefore rejects the neo-classical abstraction of consistency in preferences and behaviour.

\section{Methodology: Case Study Based Teaching}


The case study method is well established in business schools teaching (Rendtorff: 2015). The case in this article follows a qualitative method (Stake, 1995; and Yin, 2003), and aims to investigate and develop students' understanding of the lived experience, from the viewpoint of those being studied. The case focus was on the humanistic characteristics of corruption and white collar-crime, thus on the recurring socio-economic and BE essential features of white collar crime. This teaching cases was also constructed '...for analytical purposes to produce insight into the phenomena in question' (Chell, 2008: 212). Further, the theoretical sampling or selection of the case was also purposeful, as it was selected to provide interesting examples of the phenomena being researched (Punch, 2005: 187).

It is also notable that according to Megone (2002) one way to use a case history is as a presentation of experience, which would permit students the opportunity to analyse and reflect on real world behaviour. For example, Rendtorff has stated that the case methodology has the facility, '...for developing ethical judgment in the tension between theory and practice' (2015:49). He also states that case studies can, ‘... improve personal integrity and the ability to choose right action' (Ibid: 54).

\section{The Social Economic Characteristics of the Madoff Case}

Madoff was the most high-profile of a number of white-collar criminals that were exposed by the GFC and its aftermath.

'Besides the Madoff saga, Marquet International, a consultancy, has identified more than 300 sizeable Ponzi schemes from the past ten years, with combined losses for investors of 
$\$ 23$ billion. It estimates that up to half of those were affinity-based. No one has a reliable number for smaller frauds over the same period, but guesses range from $\$ 5$ billion to $\$ 20$ billion. In all, affinity-fraud losses in America could be as much as $\$ 50$ billion’ (Economist, 2012; 28 th January).

On one level each fraud represented a unique set of circumstances with its own case history and unique protagonists and human factors. At the same time however, the number and scale of these crimes indicate that there were broader factors at play, which can be understood from a social economic analysis. These social economic factors included culture values that had a narrative lauding the rugged individualism of the entrepreneur. In this narrative these 'risk takers' demonstrated how rational actors could succeed in a free market, the personification of the socalled 'entrepreneurial society', while the negatives of entrepreneurship, for instance of deception, and authoritarianism were under-reported (Brenkert, 2002). Madoff whatever his criminality could lay claim to being an innovator who had been entrepreneurial in his alertness to new opportunities. He thus exploited these cultural values to facilitate his fraud and garnish his reputation.

For illustration, Madoff was assiduous in his cultivation of his entrepreneurial reputation, both as an innovator, and as 'America's Financial Guru'. Madoff possessed undoubted entrepreneurial flair and took the credit for the exploitation of computer technology to automate stock trading. He claimed to have constructed a computer based stock market the using the Cincinnati Stock Exchange Licence to create an automated stock market. The rules at Cincinnati Stock Exchange were known for their leniency, which perhaps attracted Madoff investment. It is also worth 
noting that the speed of technological change, which Madoff very much a pioneered, posed challenges to the financial authorities, who found decentralized trading difficult to regulate or perhaps to fully understand in terms of its potential to facilitate criminal activity (Arvedlund, 2009: 40-44).

In promoting technology trading Madoff also established himself as a vocal lobbyist for deregulation: he donated heavily to both the Democratic and Republican campaigns and sat on a number of committees advising on stock market restructuring, as well as acting as the chairman of NASDAQ. It is also significant that Madoff operated a hedge fund, and these funds were not required to register with the SEC until 2006, and hence were not subject to any regulatory scrutiny (Arvedlund, 2009: 151). Madoff therefore exploited technology innovations, as well as regulatory lacunae to promote his firm and his criminal activity. A by-product of this selfpromotion was to establish Madoff with a level of credibility that was seemingly unassailable. He was a "Wall Street' legend, beyond reproach, and his influence was such that Markopolos, a certified fraud examiner, warnings over fraud were ignored: ' ...it seemed that Madoff had cast a shadow over the SEC' (Arvedlund, 2006).

\author{
Furthermore, as a leading financial entrepreneur Madoff acted as an advisor to the Securities \\ Exchange Commission (SEC) on market structure and other issues, which bolstered his carefully \\ cultivated image of the consummate professional insider. Madoff would further boast that he had \\ married his family into the SEC: his niece Shana had married an SEC staffer Eric Swanson, who \\ was part of a team overseeing the regulation planning of technology trading at the commission
}


(Arvedlund, 2009, p. 201). Madoff grip over the was such that he would claim that every time a SEC investigator came to his office they would ask for a job application (Lewis, 2012: 73).

Madoff also used his reputation as an entrepreneur to aggressively market his products to gullible charity commissioners and hence provided a lucrative source of investors. The success of the Madoff's in convincing charities to invest in his fraud can be gauged by the reforms being planned to charitable foundations altering their size and structure in order to decrease their reliance of 'personal ties' (Jagpal and Craig, 2009).

In sum, the following observation is apt: 'As Adam Smith well understood, economic life is deeply embedded in social life, and it cannot be understood apart from customs, morals, and habits of the society in which it occurs. In short, it cannot be divorced from culture' (Fukuyama, 1996: 13). Madoff, along with a number of other white-collar criminals therefore exploited the cultural values of the time that were too uncritical of entrepreneurs.

This evaluation is also confirmed by criminology theory (Payne, 2012: 435-462). Madoff in the euphoria of in the neo-liberalism of the nineties and noughties, can be analysed with reference to 'Institutional Anomie Theory'. This theoretical lens explains white-collar crime with reference to a macro-level analysis, which contends that contemporary societal norms over-promoted values associated with financial success and materialism, while under-promoting ethical values and the legality.

Finally, the commonplace nature of the Bernard L. Madoff Investment Securities (BLMIS) fraud did prevent the case achieving a level of infamy not shared by other GFC exposed crimes. Madoff's investment fraud attained a symbolism in excess of being just another example of a 
gifted con man swindling the affluent out of their investments, rather Madoff came to personifying the discredited values that led to the financial crash of 2007: to some critics he became responsible for the crash (Hurt 2009, p. 961). One can speculate that Madoff's success in promoting himself as the leading financial entrepreneur explains why some critics erroneously claimed that he had cause the GFC.

\section{Corruption and White Collar-Crime}

The case was also motivated in response to the Principles for Responsible Management Education (PRME) and its 'issue area' of 'Anti-Corruption and Ethics', which aims for MBA curriculum change (http://www.unprme.org/resources/display-resources.php?cid=3).

The case was delivered to a cohort of 20 international MBA students taking an elective module in business ethics in a UK University. Previous lectures had introduced these students to the leading ethical theories applied to business. In preparation for the teaching students were supplied with a brief chronology of the financial fraud, and were also instructed to read various relevant sources (Arvedluund, 2009), as well as a detailed depiction of Madoff's rise and fall serialized by : 'Vanity Fair' April 2009, (available at:

www.vanityfair.com/news/2009/.../bernard-madoff-). Students were then asked to discuss and present a response to two broad interpretations of the financial fraud.

The first interpretation referenced the BE insight comparing, 'Econs and Humans' (2011: 343344). This insight focussed on comparing and contrasting the BE approach to the rational choice economics. Kahneman's view that the only test of rationality in economics is whether a person's 
beliefs and preferences are consistent was introduced and discussed in a critical discussion of the rational agent model (2011: 411-415). To explore the validity of this observation, additional sources were introduced to the students, including a discussion of Granovetter's social economic insight that:

'...one's economic interest is pursued only by comparatively gentlemanly means. The Hobbesian question-how can it be that those who pursue their own interests do not do so mainly by force and fraud-is finessed by this conception. Yet as Hobbes saw so clearly there is nothing in the intrinsic meaning of 'self-interest' that excludes force of fraud' (1985: 488).

The question was posed whether the most transparent examples of rationalists in the market place are white-collar criminals who act in accordance with complete self-interestedness? Bernie Madoff from this vantage, could be taken as an extreme rationalist who ruthlessly promoted his own interests (self-interested utility optimisation) without regard to any non-rational or moral frameworks concerned with jsutice. Therefore, it could be contended that Madoff was acting in full accordance with the precepts of the dominant neo-classical economic paradigm.

The second interpretation, termed 'deontic justice' required the students to consider the standard of justice meted out to Madoff and his investors. Students were informed that on the $29^{\text {th }}$ June 2009 Judge Denny Chinn dismissed the notion of 'life expectancy analysis' that Madoff's defence attorney had requested, preferring to hand down, in his words, a 'symbolic verdict' of 150 years or 1,800 months: Madoff would be 221 before he could be considered for release on November $14^{\text {th }} 2139$. Jude Chinn elaborated that the verdict was symbolic in terms of, retribution, deterrence and for symbolism as the victims came from all walks of life (Sentencing Transcript dated June 29, 2009: 4, available at: www.justice.gov/.../united-states-v-bernard-1madoff-and-related-cases). 
It was also stressed that Madoff was not the only white-collar criminal exposed by the down turn after the crash, as a number of Ponzi schemes were soon uncovered and prosecuted, with each of the perpetrators sentenced to long prison sentences. The most high-profile of these Ponzi schemes were those perpetrated by Tom Peters who swindled $\$ 3.65$ billion, sentenced to 50 years in 2008; R. A. Stanford who swindled \$8 billion, and was sentenced to 110 years in 2009; and S Rothstein who swindled $\$ 1.2$ billion, and was sentenced to 50 years in 2010 . These sentences contrast with earlier cases of high profile white collar criminals. For example, in 2003 Jordon Belfort, the so-called \Wolf of Wall Street', was sentenced to 39 months in prison after pleading guilty to ten counts of money laundering and securities fraud,. Another well -known white collar criminal was Ivan Boesky, sentenced in 1986 to 3 years: he served 2 and half years. Boesky's plea bargaining led to another well-known fraudster, Michael Milken being convicted of 98 counts of racketeering and fraud. Milken was given a sentence of 10 years but was paroled after serving 22 months.

It was discussed that these earlier sentences were not an anomaly associated with the late twentieth and first eight years of the twentieth century, but rather were consistent with the sentencing of white-collar criminals throughout the twentieth century. For example, the whitecollar criminal who most resembles Madoff was Richard Whitney, who served as president of the New York Stock Exchange from 1930 to 1935. His financial fraud was prosecuted in 1938 and he received a sentence of 5 to 10 years, being released after serving just over 3 years. The prison term of Carlo Ponzi, whose name is usually mentioned in any article about embezzlement, provides another example. Ponzi was sentenced to 5 years, for his eponymous embezzlement in 
1920, however, he as released in 1924, after which he launched another criminal scheme based on land fraud in Florida.

\begin{abstract}
In sum sentencing for financial crime has been more draconian in recent times, as demonstrated in the symbolic prison sentence of Madoff, and students were directed to consider this development from a deontic justice perspective. Thus, to consider whether these prison sentences were just or whether they reflected contemporary society's obsession with wealth that was outraged by financial crime.
\end{abstract}

For this interpretation students were also informed that according to Madoff the investors were complicit in the fraud, as they knew the returns were too good to be true and rather than ask awkward questions they were prepared to feign ignorance. This version of reality is typical of white collar criminals, and in criminology is known as 'neutralizing theory' in which criminals rationalize their behaviour by blaming the victims (Haugh, 2014). Hurt (2009), Lewis (2012), and Cassell and Erez (2011) have all noted that the investors were vigorous in trying to establish a narrative in which they were entirely innocent victims, perhaps to assist them in their 'clawback' aims to recover assets from the authorities. Students were asked to review and reflect on the victim impact statements, which aimed to permit victims to personalize and detail the impact of crime, termed therapeutic justice. In the United States V Bernard L. Madoff, 167 substantial statements were submitted, from which the prosecution chose to submit 113 substantial statements, with 9 permitted to speak at the sentencing trial. The victim impact statements are therefore unrepresentative, but valuable for their role in 'shaping the Madoff narrative' in the sphere of public opinion. For example, the statements articulated an acute sense 


\begin{abstract}
of Madoff's treachery, not only to individual investors but more so to the wider community (www.justice.gov/.../united-states-v-bernard-1-madoff-and-related-cases).
\end{abstract}

\begin{abstract}
In sum, for this interpretation students were required to reflect on whether Madoff had received a just prison sentence or had been punitively punished because he had transgressed contemporary values, which it could be argued have elevated financial self-interest to society's organising principle. For this interpretation students were required to consider whether the investors should be regarded as victims or willing collaborators and whether they had a deontic justice case to receive compensation for their losses.
\end{abstract}

\title{
Reflections on the Case
}

A number of students were already aware of the Madoff fraud, however their knowledge was not extensive, which was advantageous as it meant that they approached the case history without firmly established preconceptions. The two interpretations were designed to give students a focus and they succeeded in directing student attention towards behavioural economics and behavioural ethics and deontic justice.

The first 'Econs and Humans' interpretation provoked stimulating responses that argued that the rational model was unrealistic and needed to be augmented with an ethical framework and moral awareness. The collective student conclusion was that Madoff was acting in accordance within the rational choice expectation of motivation and behaviour. This interpretation was developed to consider the view that there is no reason for a rationalist to exclude force or fraud, other than the risk of being apprehended and punished. It was noted by the students however, that in economic 
behaviour there are many instances when individuals could use force or fraud with little chance of being caught, but choose not to: hence 'policing mechanisms' do not explain typical economic action not to behave unethically. An alternative understanding discussed was that the economy needs human values related to ethics to function. Trust, for example was discussed as being integral to the successful functioning of the market system. In sum the students reached the view that the strictures of rational choice economics do not allow for adequate consideration of human values that behavioural economics correctly identifies as central to real-world behaviour.

For the second deontic justice' interpretation, the student response was that Madoff's punishment was unduly harsh and should be reduced for justice to be truly served. The view was that he deserved to be punished, but that the tariff was more than you would receive for crimes considered more heinous, and hence needed to be revisited. The interpretation on whether the investors were victims or silent collaborators of Madoff produced alternative conclusion, with contrasting and strongly held opinions expressed for and against the Madoff's investors. No agreement was reached on which interpretation was correct, which provided a good illustration of the contested nature of business ethics.

In overview, the ambition of the case history was to enhance MBA students' understanding of financial fraud, and to contribute to an expanded appreciation of white-collar crime, which would also serve to contribute to the anti-corruption curriculum as recommended by the WTO. Further in the context of the criminality, exposed by the GFC there is a vital need to introduce students to alternative economic paradigms beyond rational choice economics. The conclusion is that case histories, using various literary and archival sources taken from the court records in 
the public domain, have the potential to enhance teaching and learning in business and management and business ethics education.

\section{Conclusion and Recommendations}

Etzioni has averred that: '... the main obstacle to subjecting the neoclassical paradigm to the kind of competition it so strongly favours is that critics of the neoclassical paradigm have been unable to develop a reasonably parsimonious paradigm of their own' (210, p. 381). This paper has aimed to contribute to the study of economic phenomenon outside a neo-classical framework with a BE analysis of white collar crime and thus to contribute to a new paradigm combing $\mathrm{BE}$ and social economics. The paper has made the case that BE and social economics can both be thought of as heterodox to the neo-classical paradigm. The teaching case also aimed to direct students to a greater appreciation of socio-economics in the context of the GFC by using a BE analysis, as both of these economic understandings share deontological and Kantian characteristics.

For future research on corruption and white-collar crime, the recommendation is to focus teaching on equipping students' to appreciate the perennial socio-economic and BE characteristics of fraud. For example, cyber-crime is not only about criminals exploiting new technology; it is also about criminals developing proximity and trust with investors, as well as on them exploiting culture values that favour entrepreneurial innovation over established ways of doing business. It follows therefore that a socio-economic perspective can contribute to developing students understanding of anti-corruption initiatives, and also to measures charged at countering white-collar crime. A BE perspective could also be deployed to increase understanding of cyber-crime by considering influences on decision making, to limit the damage 
of bad decisions.

It is also worth noting that though neo-classical economics remains dominant, it is also accurate to assert that in the chronology of economic and intellectual history: 'The lesson is that today's heterodox thinking may become tomorrow's orthodoxy' (Boyle 1999: 48). One could argue that the contemporary rise in importance of BE is part of this process that has the potential to revitalise the importance of social economics.

This paper was written in full accordance with the requirements of the Committee on Publication Ethics (COPE).

\section{References}

Arvedluund, E (2009), Madoff, The Man who Stole \$65 Billion, Penguin, London.

Brenkert, G. (2002), “Entrepreneurship, Ethics and the Good Society”. In, Ethics and

Entrepreneurship. The Ruffin Series 3. Society for Business Ethics Charlottesville: 5-43.

Cassel, P.G., and E. Erez, (2011),"Victim Impact Statements and Ancillary Harm: The American Perspective.” Canadian Criminal Law Review, 15, pp. 149-196.

Coughlin, M. R. (2016), Morality, Rationality and Efficiency: New Perspectives on Socioeconomics: New Perspectives on Socio-economics. Routledge, London.

De Cremer, D. Mayer, David M. and Schminke, Marshall (2010), Special issue-behavioral ethics: A new empirical perspective on business ethics research-guest editors' introduction-on understanding ethical behavior and decision making: A behavioral ethics approach. Business Ethics Quarterly, Vol 20, pp.1-6. 
Etzioni, A. (1987), Toward a Kantian Socio-Economics, Review of Social Economy, Vol 45, No

1, pp.37-47.

Etzioni, A. (1988) The Moral Dimension: Toward a New Economics, New York, The Free Press.

Etzioni, A. (1999), Essays in Social Economics, Springer-Verlag, Berlin.

Etzioni, A. (2011), "Behavioral Economics: Toward a New Paradigm", American Behavioral

Scientist, 55(8) pp. 1099-1119.

Etzioni, A., Piore, M. and W. Streeck (2009), "Discussion Forum: Behavioural Economics"

Socio-Economic Review, Vol 8, 2, pp. 377-397.

Folger, R. (2011), “Behavioral ethics: A deontic perspective.” In David de Cremer \& Ann E.

Tenbrunsel (eds.), Behavioral Business Ethics: Shaping an Emerging Field. London. Routledge

Academic.

Frank, R. H. (1988), Passions Within Reason: The Strategic Role of the Emotions, W.W. Norton, New York.

Fukuyama, F. (1995), Trust: The Social Virtues and the Creation of Prosperity, Simon Schuster \& Press, New York.

Ghoshal S. (2005), "Bad management theories are destroying good management practices", Academy of Management Learning and Education, Vol. 4, No 1, pp. 75-91.

Giacalone, R.A. \& Wargo, D. T. (2009) "The Roots of the Global Financial Crisis are in Our Business Schools", Journal of Business Ethics Education, Vol. 6, pp. 147-168.

Gilad, B., Kaish, S., Loeb, P.D., (1984), “From economic behavior to behavioral economics: The behavioral uprising in economics", The Journal of Behavioral Economics 13, 1-22.

Granovetter, M. (1985), "Economic Action and Social Structure: The Problem of

Embeddedness”, American Journal of Sociology. Vol. 91, Number 3, pp.481-510. 
Granovetter, M. (2005), “The Impact of Social Structure on Economic Outcomes” Journal of Economic Perspectives, Vol. 19, No 1, pp. 33-55.

Huehn, M. P. (2014), "You Reap What You Sow: How MBA Programs Undermine Ethics", Journal of Business Ethics, Vol. 121, No 4, pp. 527-541.

Hurt, C. (2009), "Evil has a New Name (and a New Narrative): Bernard Madoff" Michigan State Law Review, pp. 947-987.

Jagpal, N and Craig, J. (2009), "Learning from Madoff: Lessons for foundations Boards." National Committee for Responsive Philanthropy.

Kahneman, D. (2011), Thinking, Fast and Slow. Farrar, Straus and Giroux, London.

Victor Kiam (1991), Going for It!: How to Succeed As an Entrepreneur, Fontana Press, London.

Kant I. (1781/1929) Critique of Pure Reason, New York, St martin's Press.

Kirzner, I. M. (1973), Competition and Entrepreneurship, The University of Chicago Press. Chicago.

Koljatic, M., \& Sliwa, M. (2015), “Do Business Schools Influence Students’ Awareness of Social Issues? Evidence from Two of Chile's Leading MBA Programs' Journal of Business Ethics, Vol. 131, pp. 595-604.

Lewis, L. S. (2012), Con Game: Bernard Madoff and his Victims. London: New Brunswick, 2012.

Lin, N. 'Social Networks and Status Attainment.' Annual Review of Sociology, 25 (1999): 467487.

Lutz, M. A. (2002), "Social economics, justice and the common good", International Journal of Social Economics, Vol. 29 Issue: 1/2, pp.26-44, 
Mollie Painter-Morland, (2015) "Philosophical assumptions undermining responsible management education", Journal of Management Development, Vol. 34 Issue: 1, pp.61-75.

Muff, K., Dyllick, T., Drewell, M., North, J., Shrivastava, P., and Haertle, J. (2013),

Management education for the world. Cheltenham: Edward Elgar.

O’Boyle, J. O. (1999), "The nature of social economics: A personal commentary", International Journal of Social Economics, Vol. 26, 1/2/3, pp.46-57.

Payne, P. (2012), White Collar Crime, The Essentials, Sage, London.

Podolny, J. M (2009), “The Buck Stops (and Starts) at Business School”, Harvard Business

Review, Vol. 87 No. 6, pp. 62-67.

Polanyi, K. (1944/1981), $2^{\text {nd }}$ Ed. The Great Transformation. Beacon Press. Boston.

Polanyi, M. (1958), Personal Knowledge. Towards a Post-Critical Philosophy, Routledge and Kegan Paul, London.

Polanyi, M. (1966), The Tacit Dimension Routledge. London.

Schumpeter, J. A. (1950), Capitalism, socialism, and democracy. Harper, Transaction Books, New Brunswick.

Smelser, N.J. and R. Swedberg Ed (1990), The Handbook of Economic Sociology: (Second Edition), Sage, New York.

Smith, I. H., E. Nechaeva E., Soderberg, A. and G. Okhuysen, (2015), "The Behavioral Ethics of Deontology and Utilitarianism: Are They as Separable as They Seem?" Academy of Management Proceedings, Vol 25, No 1.

Swanson, D. L. and W. C. Frederick. (2003), “Turning Point: Are Business Schools Silent Partners in Corporate Crime?" Journal of Corporate Venturing, Vol. 9 pp. 24-27. 
Thaler R.H. (1980), "Toward a Positive Theory of Consumer Choice. Journal of Economic

Behavior and Organization", Vol. 1, pp.39-60.

Treviño, L.K., G. R. Weaver and S. J. Reynolds (2006) "Behavioural Ethics in Organizations: A

Review", Journal of Management, Vol, 32, pp. 951-990.

Thaler, R. H. (2015). Misbehaving: The Making of Behavioral Economics. Norton and

Company, New York.

Thaler, R.H and C.R. Sunstein. (2008), Nudge: Improving Decisions about Health, Wealth and

Happiness, Yale University Press, New Haven \& London.

Tversky, A. and Kahneman, D. (1974), "Judgment under Uncertainty; Heuristics and Biases'

Science, Vol. 185, No. 4157. (Sep. 27), pp. 1124-1131.

White, M. (2011), Kantian Ethics and Economics: Autonomy, Dignity, and Character.

Stanford University Press, Stanford. 


\section{Title Page}

Title: Behavioural Economics and Social Economics: Opportunities for an Expanded Curriculum

\section{Author Contact Details:}

\section{Paul Manning}

The University of Chester, Queen's Park Campus, Room 122, Churchill House, Handbridge, Chester, CH4 7AD.

Telephone: 01244512568

E-Mail: p.manning@chester.ac.uk Mobile: 07453857677 